КРАСОВСКАЯ Наталия Рудольфовна - кандидат психологических наук; Аппарат Государственной Думы ФС РФ (125007, Россия, г. Москва, ул. Охотный Ряд, 1; goulina@gmail.com)

ГУЛЯЕВ Андрей Анатольевич - кандидат философских наук, доцент Московского государственного университета технологий и управления им. К.Г. Разумовского (ПКУ) (109004, Россия, г. Москва, ул. Земляной Вал, 73; andrey.gulyaev1966@yandex.ru)

ЛАХТИН Артем Юрьевич - кандидат педагогических наук, доцент Московского государственного университета технологий и управления им. К.Г. Разумовского (ПКУ) (109004, Россия, г. Москва, ул. Земляной Вал, 73; skbpgu@таil.ru)

ВАКУЛЕНКО Антонина Николаевна - кандидат педагогических наук, доцент Московского государственного университета технологий и управления им. К.Г. Разумовского (ПКУ) (109004, Россия, г. Москва, ул. Земляной Вал, 73; antoninanv@таil.ru)

\title{
ТЕХНОЛОГИИ ИНФОРМАЦИОННЫХ ВОЙН ПРОТИВ РОССИИ
}

Аннотация. Предметом данной статьи являются технологии ведения информационных войн против России. Методологическое основание исследования составляет содержательный анализ научных работ по информационным войнам и властным отношениям; объектом информационных атак против России являются способы реализации власти, к которым можно отнести ресурсы (человеческие и материальные), свод норм и правил, убеждения. Как видно на примерах современной прессы, каждой информационной атаке предшествует мнимый или реальный информационный повод, и нацелена она на один или несколько способов реализации власти. Целью подобных атак является такое изменение политики государства (вплоть до смены политического режима), которое отвечает интересам западных стран. Идеологической подоплекой технологий ведения информационных войн против России выступает такое проявление ксенофобии, как русофобия.

Ключевые слова: информационная война, информационный повод, способы реализации власти, санкции, русофобия, суверенитет

\section{Введение}

Информационные войны между государствами в современном мире стали повседневной реальностью. Целью подавляющего большинства информационных войн является влияние на политику государства, против которого ведется информационная война. Политика государства может измениться в силу различных причин, в ряду которых далеко не последнее место занимает лишение политической элиты власти либо ее ослабление.

Понятие информационной войны появилось всего лишь несколько десятилетий назад, но на самом деле эта война стара как мир. Человечество научилось вести ее много тысяч лет назад. Иногда такую войну еще называют психологической, и в широком смысле - это комплекс действий, направленных на изменение сознания вашего противника, внедрение в него нужных вам установок. Информационная война может вестись или непосредственно в ходе боевых действий, или же предшествовать им. Основная задача информационной войны в военное время - деморализовать армию противника, сломить ее волю к сопротивлению, склонить к капитуляции. Информационная война неразрывно связана с таким термином, как пропаганда.

Информационные войны в современном мире могут вестись и без непосредственных боевых действий. Зачастую население страны, на которую направлена информационная атака, даже и не догадывается об этом. В этом случае цели информационной войны очень просты: привести к смене политического режима в стране или максимально ослабить его. Современная «традиционная» война очень дорога, а информационные способы воздействия - прекрасная 
ей альтернатива, довольно эффективная и не требующая от агрессора жертв. Повсеместное распространение Интернета позволяет современным пропагандистам проникнуть практически в каждый дом [Панарин 2012: 198-199].

Методологическим основанием исследования является содержательный анализ научных работ по информационным войнам и властным отношениям, а также обсуждаемых публикаций в СМИ.

\section{Результаты}

Россия является излюбленным объектом для информационных атак. Начиная с эпохи Ивана Грозного и до наших дней европейские страны, а шире западные страны без устали создают мифы о России. Почему с эпохи Ивана Грозного начались информационные атаки на Россию, и почему они так усилились в последние годы? Ответ очевиден - Западу не нравится самостоятельность и суверенитет России, ее «самодержавность», отстаивание своих национальных интересов [Савин 2016: 165-166]. Технологии информационных атак на Россию оттачиваются не одно столетие, а цифровая эпоха решительным образом модернизировала арсенал информационного оружия Запада против России.

Ключевой целью информационных войн является лишение власти или ее ослабление ради навязывания своей воли и лишения суверенитета другой страны. Способы реализации власти в России являются ключевыми объектами информационных атак Запада, и прежде всего США. Способы реализации власти можно условно разделить таким образом.

А. Сила (контроль над человеческими и материальными ресурсами):

1) человеческие ресурсы:

- внешние (цель информационной атаки - лишить Россию ее союзников);

- внутренние (цель информационной атаки - внести раскол в политическую элиту России);

2) материальные ресурсы:

- лишить Россию экономических ресурсов (введение санкций с целью подрыва экономики);

- не допустить роста контролируемых ресурсов у России (блокировать реализацию новых проектов с различными государствами-партнерами и компаниями).

Б. Свод норм и правил.

Цель информационной атаки: добиться общественного и международного признания несоответствия объекта информационной атаки - России - нормам цивилизованного общества, обвинить в нарушении этих норм и законов, международного права.

В. Убеждение (вера).

Цель информационной атаки: подрыв авторитета политического лидера, в Т.Ч.:

- констатация снижения политического влияния и рейтинга политического лидера;

- подрыв имиджа команды политического лидера [Мойзес 2016: 50-52].

Ведущей технологией проведения информационных войн против России является создание крайне негативного образа государства и общества. В самом общем и крайнем своем выражении этот образ имеет русофобский характер [Соловей 2015: 206]. Следовательно, идеологическая подоплека технологий информационной войны против России сводится к одному из проявлений ксенофобии - русофобии. И все уверения Запада в толерантности и демократичности являются не более чем уловкой для наивных обществ. 
Технология информационной войны на основе русофобии осуществляется с помощью различных методов. К первому методу можно отнести создание негативного имиджа политической элиты государства. Чтобы негативный имидж был обоснован, приводятся обвинения руководства России в коррупции и подавлении демократии в стране, агрессивной внешней политике (с «доказательствами» или без оных, как само собой разумеющееся). «Авторитарная клептократия, которая держится у власти благодаря доходам от нефти и газа и подавлению оппозиции, развернувшая агрессию против Грузии, Украины, Сирии и вмешивающаяся в выборы в западных странах» - таков примерный рефрен обвинений руководства России многими западными СМИ [Баранова 2016: 622].

Второй метод расширяет предмет информационных атак. От нападок на руководство России на Западе переходят на все российское государство. «Бензоколонка, притворяющаяся государством», - слова известного американского сенатора-республиканца, «ястреба» и русофоба покойного Джона Маккейна подчеркивают саму суть информационной войны против России 1 . Здесь подразумеваются сырьевой характер российской экономики, ничтожность ее человеческих ресурсов и никчемность ее руководства. Уничижительная характеристика России как государства в словах Маккейна является симптоматичной для западных СМИ. Так, они крайне пессимистично оценивали и возможности проведения в России Чемпионата мира по футболу, и строительство Керченского моста. Создавая крайне отрицательный имидж российского руководства и государства в мировом общественном мнении, западные информационные агрессоры добиваются одновременно нескольких целей, а именно введения и ужесточения санкций против России (уменьшение силы и ресурсов у руководства), уменьшения ее «мягкой силы» (степень привлекательности страны за счет ее политической системы, идеологии, искусства и культуры), изоляции ее на международной арене и превращения в страну-изгоя (нарушение норм и правил), уменьшения влияния на постсоветском пространстве, сдерживания ее экономического, научно-технического развития, роста протестных настроений внутри страны (уменьшение доверия к власти) [Крикунова 2012: 103].

Самая яростная информационная атака на Россию в последнее время была связана с делом Скрипалей. Обвинения России в отравлении Скрипалей в Великобритании являются информационным поводом для ужесточения санкций против России и уменьшения ее материальных ресурсов. Обвинение России в применении химического боевого отравляющего вещества (пресловутый «Новичок») на территории другого государства имеет другое далеко идущее последствие - это обвинение России в нарушении принятых ею обязательств по неприменению и уничтожению запасов химического оружия. Обвинение в нарушении обязательств, по идее авторов этой информационной атаки, должно подорвать основы легитимности политического режима в России.

Информационные атаки на Россию с целью расшатать основы легитимности российского руководства направлены на взятые Россией обязательства и мнимое их нарушение. Информационных поводов для этих атак было создано множество, начиная с грузино-югоосетинского военного конфликта [Соловьев 2010: 77-78], когда Россию обвиняли в развязывании войны и оккупации части территории Грузии. Затем в 2011-2012 гг. последовали обвинения властей России в фальсификации и недемократичности выборов в Государственную

1 Маккейн: Россия - это бензоколонка, которая притворяется страной. - ИноТВ. 16.03.2014. Доступ: russian.rt.com (проверено 24.02.2019). 
думу. Помимо западных СМИ, эти обвинения были озвучены некоторыми политическими деятелями, такими как, например, занимавшая тогда пост госсекретаря США Хиллари Клинтон (как здесь не вспомнить абсолютно недемократический заговор ее предвыборного штаба против претендента на пост президента США П. Сандерса спустя 5 лет, в 2016 г.) [Баранова 2016: 625]. В 2013 г. звучали обвинения России в том, что она не выдает бежавшего сотрудника спецслужб США Э. Сноудена, в марте 2014 г. Россию обвинили в аннексии Крыма. Дальше - больше. Россию обвинили в гибели пассажирского авиалайнера под Донецком, поставке вооружения и добровольцев в Донбасс. В 2015-2017 гг. прозвучали обвинения в употреблении допинга российскими спортсменами под прикрытием государственных органов, во вмешательстве в выборы в США и других странах. В 2018 г. прозвучали обвинения в отравлении Скрипалей в Великобритании и инциденте в Керченском проливе. В том же году США объявили, что Россия нарушает Договор о ракетах средней и меньшей дальности, и уже в 2019 г. президент США Д. Трамп заявил, что его страна выходит из этого договора, как при Д. Буше-младшем США вышли из другого договора - о противоракетной обороне - без объяснения каких-либо причин.

Отдельной темой является такой ресурс власти, как убеждения или вера (доверие) общества политическому лидеру и руководству. Как отметил В. Сурков, в России существует так называемый глубинный народ. Какие бы прекрасные на первый взгляд реформы власть ни планировала, все они сталкиваются с реальностью существования «глубинного народа». Именно благодаря ему многочисленные завоеватели России остались ни с чем. Этот народ горд, потому что не был никем завоеван и может доверять только лидеру, а не коллективному руководству в лице правительства или парламента. В обывательских разговорах «глубинный народ» может нелицеприятно высказываться о лидере, но в минуту опасности сплотится вокруг него ${ }^{1}$. Информационные атаки западных СМИ на В.В. Путина преследуют цель демонизировать его в глазах международной аудитории и лишить ореола харизматичности внутри страны. Но, как метко уже подметили в «глубинном народе», если Путина ругают за рубежом, значит, он все правильно делает, и наоборот. Те же самые западные СМИ и политические деятели, что ругают Путина, хвалили Горбачева и Ельцина. Последние у «глубинного народа» имеют резко негативные характеристики.

Стремление США и Европы внести раскол в политическую элиту России стало главной причиной введения персональных санкций против отдельных ее представителей. Так, например, США ввели жесткие санкции против О. Дерипаски и его компании «Русал», стремясь наказать и отторгнуть от Кремля якобы близких к нему олигархов.

На наших глазах разворачивается борьба за «Северный поток-2». США пытаются заблокировать этот энергопроект России и Германии, выгодный также Австрии и другим европейским странам, которым нужен надежный и бесперебойный транзит сравнительно дешевого природного газа (по сравнению с дорогим сжиженным американским газом), угрожая санкциями всем тем, кто поддерживает этот энергопроект. Еврокомиссия уступает нажиму США и некоторых восточноевропейских стран (таких, как Польша) и занимает все более проамериканскую позицию, пытаясь ввести всевозможные ограничения на объем природного газа, который будет поступать в будущем при условии реализации «Северного потока-2». США, угрожая сорвать этот энергопроект, преследуют сразу две цели: ограничить материальные, экономические ресурсы России и ее

\footnotetext{
1 Сурков В. Долгое государство Путина. - Независимая газета. 11.02.2019. Доступ: ng.ru/ideas/201902-11/57503 surkov.html (проверено 15.02.2019).
} 
влияние на Германию и Австрию, а также, что немаловажно, заставить покупать европейцев американский природный газ, тем самым преследуя свой корыстный интерес и инициируя нечестную конкуренцию.

\section{Заключение}

С наступлением 2019 г. тема Скрипалей как повод для информационных атак на Россию отошла на второй план. Сейчас наиболее перспективными для западных политических деятелей и СМИ являются «керченская» и «венесуэльская» тема. В первом случае, если провокация ВМС Украины в Керченском проливе повторится, Россию вновь обвинят в агрессии против Украины и будут грозить новыми санкциями. Во втором случае Россию обвиняют в поддержке президента Венесуэлы Н. Мадуро, которого на Западе считают диктатором. Сейчас борьба за Венесуэлу ведется в Совете Безопасности ООН. России грозят еще большей изоляцией на международной арене, пересмотром роли и функций Совета Безопасности и государств, входящих в него.

В современном мире господства виртуальной реальности и новостей создать информационный повод для атаки на государство не так уж и сложно. Достаточно вспомнить постановочные кадры «последствий химических атак против мирного населения» в Сирии, в которых обвиняли руководство Сирии. Информационные атаки на Россию в обозримом будущем имеют устойчивую тенденцию к усилению [Беляев 2014: 349-350]. И острие этих атак будет направлено против молодежи - наиболее уязвимого звена общества, которая не всегда может распознать комплексное манипулятивное воздействие [Положенцева, Евсеева, Кащенко 2017].

В однополярном мире быть независимым - дорогое удовольствие. Россия выбрала независимость, и другого пути у нее нет. Как сказал президент России В.В. Путин, «Россия либо будет суверенной, либо ее вообще не будет» ${ }^{1}$.

\section{Список литературы}

Баранова Е.А. 2016. Мультимедийные технологии в средствах массовой информации как инструмент ведения информационной войны. - Bonpocы теории и практики жсурналистики. Т. 5. № 4. С. 618-628.

Беляев Д.П. 2014. Разруха в головах. Информационная война против России. СПб: Питер. 460 с.

Крикунова В.В. 2012. Мировые СМИ - инструмент политического влияния. Обозреватель - Observer. № 4. С. 101-108.

Мойзес Н. 2016. Конеи власти. От залов заседаний до полей сражения, от церкви до государства. Почему управлять сегодня нужно иначе (пер. с англ.). М.: АСТ. 512 с.

Панарин И.Н. 2012. СМИ, пропаганда и информационные войны. М.: Поколение. $336 \mathrm{c}$.

Положенцева И.В., Евсеева Т.Г., Кащенко Т.Л. 2017. Совершенствование образовательных программ по гуманитарным и общественно-научным дисциплинам: учебное пособие. М.: Университетская книга. 230 с.

Савин Л.В. 2016. Новые способы ведения войны: как Америка строит империю. СПб: Питер. 352 с.

Соловей В.Д. 2015. Абсолютное оружие. Основы психологической войны и медиаманипулирования. М.: Изд-во «Э». 320 с.

Соловьев А.В. 2010. Информационная война: понятие, содержание, перспектива. - Пространство и время. № 2. С. 75-81.

\footnotetext{
${ }^{1}$ Путин: Россия будет суверенной, либо ее вообще не будет. - RT. 06.06.2018. Доступ: russian.rt.com (проверено 16.02.2019).
} 
KRASOVSKAYA Nataliya Rudol'fovna, Cand.Sci. (Psych.), The Office of the State Duma of the Federal Assembly of the Russian Federation (1 Okhotny Ryad St, Moscow, Russia, 125007; goulina@gmail.com)

GULYAEV Andrei Anatol'evich, Cand.Sci. (Philos.), Associate Professor of the K.G. Razumovsky Moscow State University of Technologies and Management (First Cossack University) (73 Zemlyanoi Val St, Moscow, Russia, 109004; andrey. gulyaev1966@yandex.ru)

LAKHTIN Artyom Yur'evich, Cand.Sci. (Ped.), Associate Professor of the K.G. Razumovsky Moscow State University of Technologies and Management (First Cossack University) (73 Zemlyanoi Val St, Moscow, Russia, 109004; skbpgu@mail. ru)

VAKULENKO Antonina Nikolaevna, Cand.Sci. (Ped.), Associate Professor of the K.G. Razumovsky Moscow State University of Technologies and Management (First Cossack University) (73 Zemlyanoi Val St, Moscow, Russia, 109004; antoninanv@mail.ru)

\title{
TECHNOLOGIES OF INFORMATION WARFARE AGAINST RUSSIA
}

\begin{abstract}
The subject of this article is the technology of information warfare against Russia. The methodological basis of the research is the content analysis of scientific works on information wars and power relations. The object of information attacks against Russia are the ways to realize power, which include resources (human and material), a set of rules and regulations, remuneration and persuasion. As the examples from the modern press show, an imaginary or real information occasion aimed at one or more ways of realizing power precedes each information attack. The purpose of such attacks is to change the policy of the state (up to the change of the political regime), which meets the interests of western countries. The ideological background of information warfare technologies against Russia is such a manifestation of xenophobia as Russophobia.
\end{abstract}

Keywords: information war, information occasion, ways of realization of power, sanctions, Russophobia, sovereignty

МИТРАХОВИЧ Станислав Павлович - преподаватель департамента политологии и массовых коммуникаций Финансового университета при правительстве РФ (125993, Россия, г. Москва, ГСП-3, Ленинградский пр-кт, 49; spmitrahovich@fa.ru)

\section{ВЛИЯНИЕ ВREXIT НА ПОЛИТИЧЕСКИЙ И ИДЕОЛОГИЧЕСКИЙ КОНФЛИКТ ЭЛИТ ЕВРОПЫ И РОССИИ}

Аннотация. В статье рассматривается Brexit с точки зрения влияния данного процесса и концептуального проекта на отношения России и Европейского союза в интерпретации политических элит. Публичные политики, партийные лидеры и функционеры, а также прочие игроки в политическом процессе, оценивающие развитие отношений РФ и ЕС, преломляют свои оценки событий и видение дальнейших собственных стратегий и задач внешней политики с учетом возможного выхода Соединенного Королевства из Европейского союза.

Ключевые слова: Брексит, российско-европейские отношения, Европейский союз, политические партии

$\mathrm{B}$ период после 2014 г. одним из главных нервов отношений Европейского союза с Россией стала политика санкций ЕС в отношении РФ. Британский референдум же о выходе из ЕС (за это решение проголосовали 51,9\% избирателей) во многом смешивает карты сторонникам сохранения санкционного 